\title{
Cotton-supported heterotrophic denitrification of nitrate-rich drinking water with a sand filtration post-treatment
}

\author{
Claudio Della Rocca ${ }^{1 *}$, Vincenzo Belgiorno ${ }^{1}$ and Sureyya Meriç ${ }^{1}$ \\ ${ }_{1}$ University of Salerno, Department of Civil Engineering, 84084 Fisciano (SA), Italy
}

\begin{abstract}
The biological denitrification (BD) process represents an interesting solution to remove nitrate from water and as well as to close the natural nitrogen cycle. Potential applications are related to both groundwater denitrification and treatment of nitraterich effluents from reverse osmosis and ion-exchange processes. This paper presents the results obtained from a pilot-scale cotton-supported heterotrophic denitrification reactor (HDR) where cotton acts as both organic carbon source and supporting material for the growth of a denitrifier biofilm. A trickling sand filter (TSF) was inserted as post-treatment to remove TOC released by the HDR and to re-oxygenate the treated water. The system is evaluated for drinking water treatment.

Nitrate removal efficiency of the HDR was over $90 \%$ for $85 \mathrm{mg} / \ell$ of inlet nitrate concentration which is a mean groundwater value in many EU countries. The process maintained its high performance up to $358 \mathrm{mg}$ of daily nitrate inlet with a maximum specific volumetric ratio of $24.5 \mathrm{gN} / \mathrm{m}^{3} \cdot \mathrm{d}$. A first-order kinetic value was shown for sequential nitrate-nitrite and nitrite-nitrogen gas transformations. For that, the kinetic constants of $2.6 \ell / d(\mathrm{~K} 1)$ and $15.9 \mathrm{l} / \mathrm{d}(\mathrm{K} 2)$ were assumed. The TSF provided additional nitrification-aerobic denitrification at a rate of $20.7 \mathrm{gN} / \mathrm{m}^{3} \cdot \mathrm{d}$. Although both reactors showed high performances in terms of nitrogen removal, this plant configuration cannot assure an adequate TOC outlet concentration $(>3 \mathrm{mg} / \ell)$
\end{abstract}

Keywords: nitrate removal, drinking water, sand filtration, heterotrophic denitrification, cotton

\section{Nomenclature}

BD Biological denitrification

CFU Colony-forming units

CSTR Completely stirred tank reactor

DBPs Disinfection by-products

DO Dissolved oxygen

HDR Heterotrophic denitrification reactor

MVNR Maximum volumetric nitrate removal

PRB Permeable reactive barrier

PVC Polyvinyl chloride

SC Solid carbon

SCS Solid carbon source

TOC Total organic carbon

TSF Trickling sand filter

\section{Introduction}

Nitrate is one of the most important and widespread of the numerous potential groundwater contaminants. The main causes of nitrate pollution are the excessive use of fertilisers in intensive agriculture, the irrigation with domestic wastewater and change in land-use patterns (Canter, 1997; Soares, 2000).

Possible health consequences of nitrate ingestion include methaemoglobinemia, the blue-baby syndrome in infants under six months of age (Winneberger, 1982), and the possible formation in the gastric system of n-nitroso compounds which are known to be carcinogens in the digestive system (Tannenbaum

\footnotetext{
* To whom all correspondence should be addressed.

푱 +39089 96 4016; fax: +390899641 00;

e-mail: cdellarocca@unisa.it

Received 16 September 2004; accepted in revised form 4 January 2005.
}

and Green, 1985: WHO, 2003). These reasons led to the adoption of a stringent limit around $50 \mathrm{mg} / \ell$ of $\mathrm{NO}_{3}^{-}$as shown in Table 1.

Many technologies have been developed to remove nitrate from drinking water, in order to respond to the constant increase of the nitrate pollution problem. The US Environmental Protection Agency identified the best available technologies for nitrate removal as being ion exchange, reverse osmosis and electrodialysis (USEPA, 1995). However, these technologies are still uneconomical and they have disadvantages such as producing more concentrated reject (reverse osmosis), increasing other ions in the outlet (ion exchange) and more complex processes to be operated (electrodialysis) (Soares, 2000). Alternatively, biological

\begin{tabular}{|c|c|c|}
\hline \multicolumn{3}{|c|}{$\begin{array}{c}\text { TABLE } 1 \\
\text { Nitrate and nitrite limits }\end{array}$} \\
\hline & Nitrite $(\mathrm{mg} / \ell)$ & Nitrate $(\mathrm{mg} / \mathrm{l})$ \\
\hline $\begin{array}{ll}\text { USA } & \mathrm{MCLG}^{1} \\
& \mathrm{MCL}^{2}\end{array}$ & $\begin{array}{l}3.28 \\
3.28\end{array}$ & $\begin{array}{l}44.43 \\
44.43\end{array}$ \\
\hline $\begin{array}{ll}\operatorname{EEC~}(1998)^{3} & \text { MCL } \\
& \text { EDWTP }^{4}\end{array}$ & $\begin{array}{l}0.5 \\
0.1\end{array}$ & 50 \\
\hline WHO $(2003)^{5}$ & 3 & 50 \\
\hline $\mathrm{MOROCCO}^{6}$ & 0.1 & 50 \\
\hline
\end{tabular}

Guide maximum contaminant level (GMCL)

Maximum contaminant level (MCL)

Must be respected according to equation of

Effluent of drinking water treatment plant

Guideline limit (GL)

6 Guide limit applied by ONEP, Rabat Drinking Water Treatment Plant Authority 
denitrification has been extensively studied as an economical and ecologically friendly process. Heterotrophic denitrification is the biological process in which nitrate is anaerobically converted to nitrogen gas. Heterotrophic bacteria need an external source of organic carbon to develop their metabolism. Many typical simple carbon compounds have been used to support groundwater denitrification processes, such as ethanol, methanol and acetate as cited by Her and Huang (1995) and Soares (2000). Recently various studies have been conducted to evaluate the potential use of solid carbon (SC) as energy source in denitrification processes, such as cellulose-based material (Volokita et al., 1996a; 1996b; Soares and Abeliovich, 1998; Schipper and Vojvodić-Vuković, 2000; Soares et al., 2000; Aslan and Turkman, 2004) and biodegradable polymers (Boley et al., 2000). SC plays the role of a porous treatment wall which can act as permeable reactive barriers (PRB) for in situ application of biological denitrification of groundwater (USEPA, 1998). Treatment walls are constructed so that the plume passes through the wall media, in which conditions are maximised to promote biological or chemical treatment of the contaminant (Schipper and VojvodićVuković, 2000; Hunter, 2001; Schipper et al., 2004).

Cellulose is the most abundant renewable resource in the world being a basic component of all plant materials. Alternative synthetic compounds used as carbon sources, are not renewable and may display eventual toxicity (i.e. methanol) (Soares, 2000). Cellulose is composed of linear glucose polymers with hydrogen bonding between hydroxyl groups of neighbouring parallel chains (Soares, 2000). Cotton is the purest form of naturally occurring cellulose with only a small percentage of impurities mostly in the form of wax, pectin and protein residues (Volokita et al., 1996b). The use of cotton to support denitrification process in in-situ application reduces residual material in soil. Volokita et al. (1996b) showed that cotton is the best cellulose-based material with the highest specific external surface to support the hetherotrophic denitrification (HD) process.

In this study, an up-plug-flow pilot reactor followed by a trickling sand filter (TSF) were installed to evaluate cotton-supported HD to remove $85 \mathrm{mg} \mathrm{N} / \ell$ from drinking water which has been reported an average value for nitrate-rich ground water resources in European countries (EEC, 2002). The TSF was installed as post-treatment to test its ability to reduce TOC content of the treated water due to the microbial release from HDR and to increase the oxygen concentration of the treated water. The effective parameters such as nitrate flow rate, simultaneous cotton consumption, detention time and temperature on HD were investigated.

\section{Experimental}

\section{Inoculation}

To prepare an inoculum of denitrifying bacteria for the pilot plant, $5 \mathrm{~g}$ of sub-superficial soil $(0.3 \mathrm{~m}$ of depth) taken from a pristine and humic-acid-rich area (Gamble et al., 1977), was added as primary bacterial source into four flasks with 1000 $\mathrm{m} \ell$ of volume; two of them contained $2.4 \mathrm{~g}$ of cotton and other two were filled with $3.7 \mathrm{~g}$ of wheat straw for the inoculation of heterotrophic denitrification bacteria as reported by Volokita et al. (1996a) and Della Rocca (2005). Each flask contained 800 $\mathrm{m} \ell$ of tap water, which was enriched with $100 \mathrm{mg} / \ell$ nitrate (as $\mathrm{KNO}_{3}$ ), $3 \mathrm{mg} / \ell$ phosphate $\left(\right.$ as $\mathrm{K}_{2} \mathrm{HPO}_{4}$ ) sources, yielding a $\mathrm{C} / \mathrm{N} / \mathrm{P}$ weight ratio of $1000 / 22 / 3$. To improve the oxygen consumption $3.2 \mathrm{~g}$ of metallic iron was also added to two flasks (one with cotton and one with wheat straw). All batch reactors

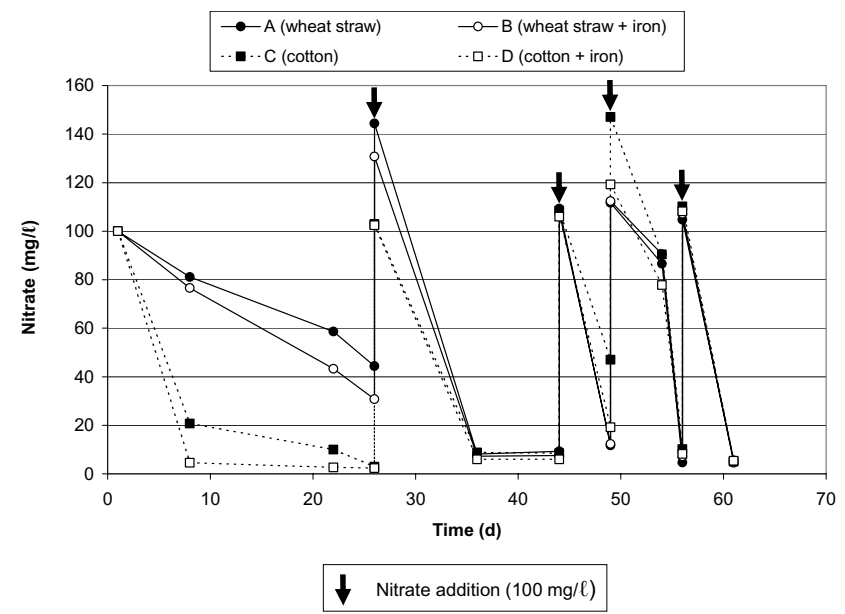

Figure 1

Inoculums preparation

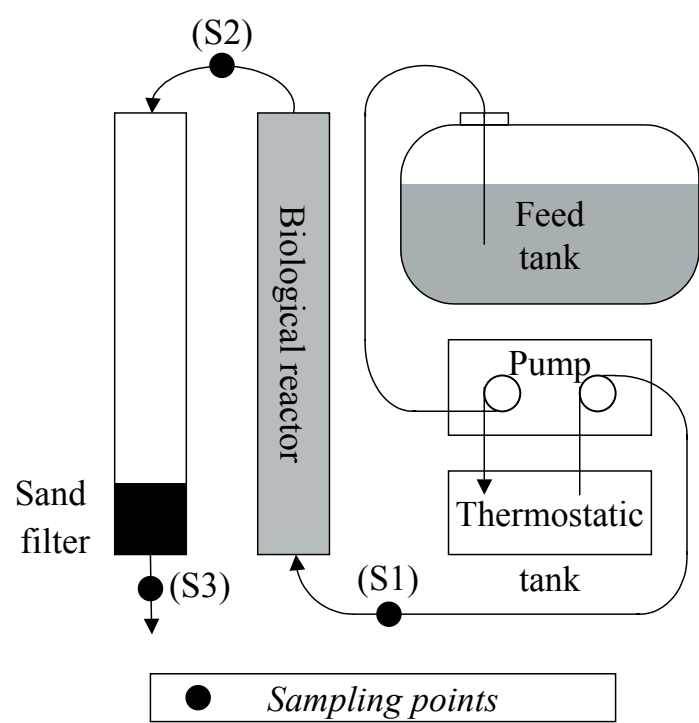

Figure 2

Experimental set-up

were sealed to create anaerobic conditions and incubated at $25^{\circ} \mathrm{C}$ for $60 \mathrm{~d}$ without agitation. They were analyzed for their nitrate concentration every 3 to $5 \mathrm{~d}$. Nitrate, phosphate and cotton were re-added to the flasks when a low nitrate concentration (below $20 \mathrm{mg} / \ell$ ) was detected (Fig. 1). While nitrate removal was higher in the flasks filled with cotton and cotton and metallic iron during the first loading, during the other nitrate loadings almost the same nitrate removals were obtained in all flasks. However, the column tests as described below were only enriched with the mixed bacteria grown in the flasks filled with both cotton and cotton and metallic iron.

\section{Continuous reactor system}

The experimental apparatus was composed of two sequential reactors; the first being a biological HDR followed by trickling sand filtration (TSF) (Fig. 2). The HDR was made up of a PVC column (900 $\mathrm{mm}$ height and with $80 \mathrm{~mm}$ internal diameter), packed with $380 \mathrm{~g}$ of raw cotton as described by Volokita et al. (1996b), with a layer of PVC fine net as filled support at the bot- 
tom of the reactor. The TSF reactor was made up of the same material as the HDR. It consisted of a column of $260 \mathrm{~mm}$ height containing bi-washed sea-sand with $2 \mathrm{~mm}$ of average diameter. The HDR was inoculated with the bacteria grown in cotton and metallic iron media. The reactors were fed by tap water of that quality is presented in Table 2. Tap water was spiked with nitrate concentration of $85 \mathrm{mg} / \ell$. The final N/P ratio was $19 / 1$. The nitrate concentration was selected according to typical nitrate contaminated groundwater as referred by EEC (2002).

The HDR was started-up in an up flow mode and fed by a peristaltic pump, which can regulate the flow rate from 0.825 to $110 \mathrm{m \ell} / \mathrm{min}(0.236 \mathrm{~m} / \mathrm{d}$ to $31.513 \mathrm{~m} / \mathrm{d})$. After three weeks a further $4.8 \mathrm{~g}$ of inoculated cotton was added to the column. To see the effect of the temperature (varied from 20 to $45^{\circ} \mathrm{C}$ ) on the denitrification process the inlet water temperature was kept thermostatically controlled. The TSF was operated in downflow trickling mode with a constant retention time (approximately 10 min) related to the trickling velocity.

\section{Analytical procedure}

The nitrate, nitrite and ammonia levels were measured in the inlet and the outlet of both the HDR and TSF. Furthermore, oxygen concentrations, TOC and bacterial counts were monitored in the inlet and outlet of TSF. All analytical methods followed are given in Table 3.

\section{Results and discussion}

\section{Heterotrophic denitrification reactor (HDR)}

\begin{tabular}{|l|c|l|l|c|}
\hline \multicolumn{5}{|c|}{ Analytical procedures } \\
\hline Parameter & Unit & $\begin{array}{l}\text { Sampling } \\
\text { point }\end{array}$ & Method & $\begin{array}{l}\text { Frequency } \\
\text { (times/week) }\end{array}$ \\
\hline Nitrate & $\mathrm{mg} / \ell$ & $\mathrm{S} 1, \mathrm{~S} 2, \mathrm{~S} 3 *$ & Standard Methods (1998) & $2-3$ \\
\hline Nitrite & $\mathrm{mg} / \ell$ & $\mathrm{S} 1, \mathrm{~S} 2, \mathrm{~S} 3$ & Standard Methods (1998) & $2-3$ \\
\hline Ammonia & $\mathrm{mg} / \ell$ & $\mathrm{S} 1, \mathrm{~S} 2, \mathrm{~S} 3$ & Standard Methods (1998) & $2-3$ \\
\hline TOC & $\mathrm{mg} / \ell$ & $\mathrm{S} 1, \mathrm{~S} 2, \mathrm{~S} 3$ & $\begin{array}{l}\text { (model 5000A, Shimadzu Cor- } \\
\text { poration, Kyoto, Japan) }\end{array}$ & 2 \\
\hline DO & $\mathrm{mg} / \ell$ & $\mathrm{S} 1, \mathrm{~S} 2, \mathrm{~S} 3$ & $\begin{array}{l}\text { (Model Handylab OX1, Schott, } \\
\text { Deutschland) }\end{array}$ & 5 \\
\hline pH & -- & $\mathrm{S} 1, \mathrm{~S} 2, \mathrm{~S} 3$ & (Model 9024, Hach Ins, USA) & 5 \\
\hline $\begin{array}{l}\text { Bacterial count } \\
\text { (Coliforms) }\end{array}$ & $\mathrm{CFU} / \mathrm{m} \ell$ & $\mathrm{S} 1, \mathrm{~S} 2, \mathrm{~S} 3$ & $\begin{array}{l}\text { Membrane filter (Standard } \\
\text { Methods (1998), M-endo agar } \\
\text { (Oxoid S.p.a) }\end{array}$ & 2 \\
\hline
\end{tabular}

\section{Start-up}

The system was operated for 5 months after the start-up phase of 4 weeks. In the first 3 weeks, inlet nitrate concentration was constant and the flow rate was regulated to $0.162 \mathrm{~m} / \mathrm{d}$ by peristaltic pump. During these 3 weeks the system was operated without inoculating the column as the control run. As expected, no denitrification occurred. On Day 23, $12 \mathrm{~g}$ of cotton inoculated with bacteria grown iron cotton + metallic iron media was added to the column to encourage denitrification. At the same time the pump was stopped for $7 \mathrm{~d}$ with a recycle of water to ensure mixing. During those 7 days $100 \mathrm{mg} / \ell$ of nitrate $\left(\right.$ as $\mathrm{KNO}_{3}$ ) was also added when a low concentration $\left(<20 \mathrm{mgNO}_{3} / \ell\right)$ was detected (Fig. 1). On the first day of the recycling mode (Day 31), complete removal of $85 \mathrm{mg}$ nitrate $/ \ell$ was achieved at an average daily flow rate of $0.162 \mathrm{~m} / \mathrm{d}(0.6 \mathrm{~m} \ell / \mathrm{min})$. After $7 \mathrm{~d}$ when the nitrate removal rate reached a steady state, the flow rate was increased to $0.859 \mathrm{~m} / \mathrm{d}(3 \mathrm{ml} / \mathrm{min})$. The nitrate removal of HDR was always over $85 \%$ at this feed rate (between 44 to $58 \mathrm{~d}$ ) and no nitrite accumulation was detected.

The maximum daily removal of nitrate $(356.27 \mathrm{mg} / \mathrm{d})$ was observed after $45 \mathrm{~d}$ at $27^{\circ} \mathrm{C}$. A nitrate removal efficiency of $97 \%$ was obtained. The maximum volumetric nitrate removal ratio (MVNR) was calculated as $0.024 \mathrm{gN} / \mathrm{m}^{3} \cdot \mathrm{d}$ and is compared with the results reported in the literature as shown in Table 4 . The MVNR value obtained in this study was relatively lower than $0.081 \mathrm{gN} / \mathrm{m}^{3} \cdot \mathrm{d}$ that was obtained by Volokita et al. (1996b). This

\begin{tabular}{|l|c|}
\hline \multicolumn{2}{|c|}{ Tap water characteristics } \\
\hline Parameter & Concentration $(\mathrm{mg} / \mathrm{\ell})$ \\
\hline Nitrate & 1.630 \\
\hline Phosphate & 0.005 \\
\hline Sulphate & 3.320 \\
\hline Chlorine & 6.730 \\
\hline Fluorine & 0.090 \\
\hline Free chlorine & 0.005 \\
\hline
\end{tabular}

* S1, S2, and S3 indicate the sampling points shown in Fig. 2

difference can be attributed to the following effects:

- A lower nitrate concentration (Table 4) was fed to the HDR with respect to the other studies (Volokita et al., 1996b; Soares et al., 2000); Consequently, in the case of two reactors having different inlet nitrate concentrations but the same daily flow rate of nitrate, that dedicated part to oxygen consumption (no denitrification occurs) would be greater in the reactor with low nitrate inlet concentration.

- The inlet phosphate concentrations varied $(1 \mathrm{mg} / \ell$ of $P$ in this study and $3 \mathrm{mg} / \ell$ of $P$ in the study by Volokita et al., 1996b).

- A different inoculum was used than Volokita et al. (1996b) who used an inoculum taken from an active denitrification column.

- In particular, it must be noted that N/P ratios were different in inoculation and running column tests during our test, e.g. an N/P ratio of 7.3/1 for inoculation and an N/P ratio of $19 / 1$ for the column test, much higher than the ratio given by Hunter (2003).

\section{Relationship between cotton consumption and nitrate removal}

No cotton was added during the $160 \mathrm{~d}$ of test. Figure 3 illustrates the maximum nitrate removal vs. time as well as with the estimated cotton consumption curve. The consumed cotton ex- 


\begin{tabular}{|l|l|c|c|c|l|}
\hline \multicolumn{5}{|c|}{ Solid and insoluble carbon source-supported nitrate removal experiences } \\
\hline $\begin{array}{l}\text { Carbon } \\
\text { source }\end{array}$ & $\begin{array}{l}\text { System } \\
\text { description }\end{array}$ & $\begin{array}{c}\mathbf{N O}_{3} \text { inlet } \\
(\mathbf{m g} / \mathbf{l})\end{array}$ & $\begin{array}{c}\text { C/N } \\
\mathbf{( g / g})\end{array}$ & $\begin{array}{c}\text { Volumetric } \\
\text { Removal } \\
\text { Ratio } \\
\left(\mathbf{k g ~ N} / \mathbf{m}^{3} \cdot \mathbf{d}\right)\end{array}$ & Reference \\
\hline Vegetable oil & $\begin{array}{l}\text { Open tank, } \\
\text { horizontal flow }\end{array}$ & 88.5 & & 0.036 & Hunter (2001) \\
\hline Newspaper & Columns study & $90-100$ & & 0.037 & Volokita et al. (1996a) \\
\hline Cotton & Columns study & 300 & 2.6 & 0.081 & Volokita et al. (1996b) \\
\hline Sawdust & PRB & $30.5-58.9$ & & 0.0003 & Shipper et al. (2000) \\
\hline Wheat Straw & Columns study & 92.9 & & 0.053 & Soares et al. (1998) \\
\hline Cotton & Pilot plant & 97.4 & & 0.060 & Soares et al. (2000) \\
\hline Cotton & Column study & $85-90$ & 2.9 & 0.024 & This study \\
\hline
\end{tabular}

pressed by the formula $\left(\mathrm{C}_{6} \mathrm{H}_{10} \mathrm{O}_{2}\right)$ was calculated as around $15 \%$ on the basis of simultaneous oxygen consumption, nitrate reduction, and TOC released as given in Eqs. (1) and (2).

$$
\begin{aligned}
& \mathrm{C}_{6} \mathrm{H}_{10} \mathrm{O}_{2}+6 \mathrm{O}_{2} \Rightarrow 6 \mathrm{CO}_{2}+2 \mathrm{H}_{2} \mathrm{O} \\
& \mathrm{C}_{6} \mathrm{H}_{10} \mathrm{O}_{2}+6 \mathrm{NO}_{3}^{-}+6 \mathrm{H}^{+} \Rightarrow 6 \mathrm{CO}_{2}+8 \mathrm{H}_{2} \mathrm{O}+3 \mathrm{~N}_{2}
\end{aligned}
$$

TOC released from the reactor was directly linked to cotton release because wash-out of the bacteria was at negligible level.

The ratio of 2.9 cotton/ $\mathrm{N}$ achieved in this study is in accord with the ratio of 3.3 cotton/ $\mathrm{N}$ measured by Volokita et al. (1996b).

\section{Effect of flow rate on denitrification process}

A linear relationship was observed between the daily nitrate input flow rate and the removal of nitrate (Fig. 4). This tendency was the same up to the breakthrough value of around $350 \mathrm{mg} / \mathrm{d}$ (between 33 to 98 d). A $91.5 \%$ mean nitrate removal efficiency was obtained. The reason why this linear relationship was observed only for a limited period (for $50 \mathrm{~d}$ ) as seen in Fig. 3. can be explained by the simultaneous effect of cotton consumption and clogging of the reactor by entrapment of $\mathrm{N}_{2}$ bubbles (Soares et al., 1989; 1991). This hypothesis is supported by the difference between initial and final reactor water volumes of $2.9 \ell$ and $1.6 \ell$, respectively. The entrapment of $\mathrm{N}_{2}$ would further be a concern causing the permeability decrease in in situ application (Hunter, 2003).

A non-linear relationship $\left(\mathrm{R}^{2}=0.879\right)$ was obtained between flow-velocity and outlet TOC as seen in Fig. 5. This relationship forces us to consider different reactor configurations to assure low- flow velocity for obtaining low TOC outlet. For instance a radial or CSTR could be evaluated instead of a plug-flow reactor.

\section{Effect of temperature on denitrification}

The effect of temperature on nitrate removal is shown in Fig. 6 . The mean temperature was calculated by the differences between inlet (S1) and outlet (S2) water temperatures. The temperature was modified between the days of 102 and 135 by varying the mean temperature from 27 to $41^{\circ} \mathrm{C}$. The maximum nitrate removal was drastically decreased when the temperature increased. This tendency was the same when the flow velocity was

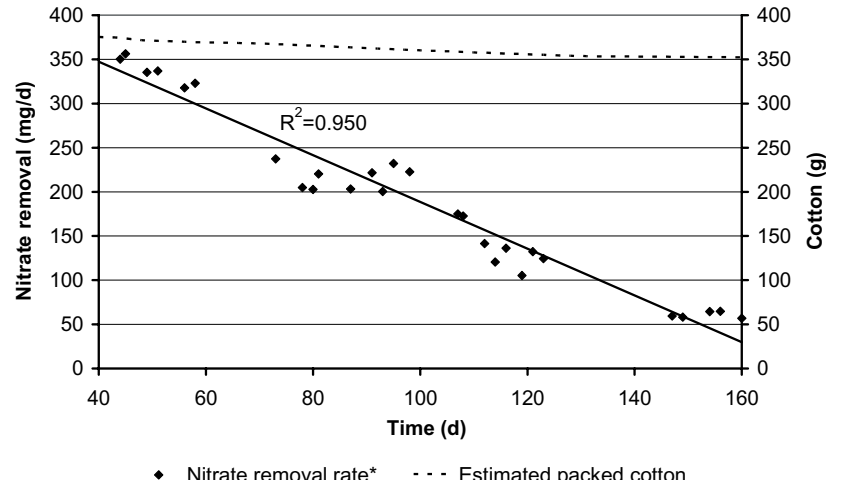

Figure 3

$\mathrm{NO}_{3}{ }^{-}$removal and cotton consumption vs. time in the HDR

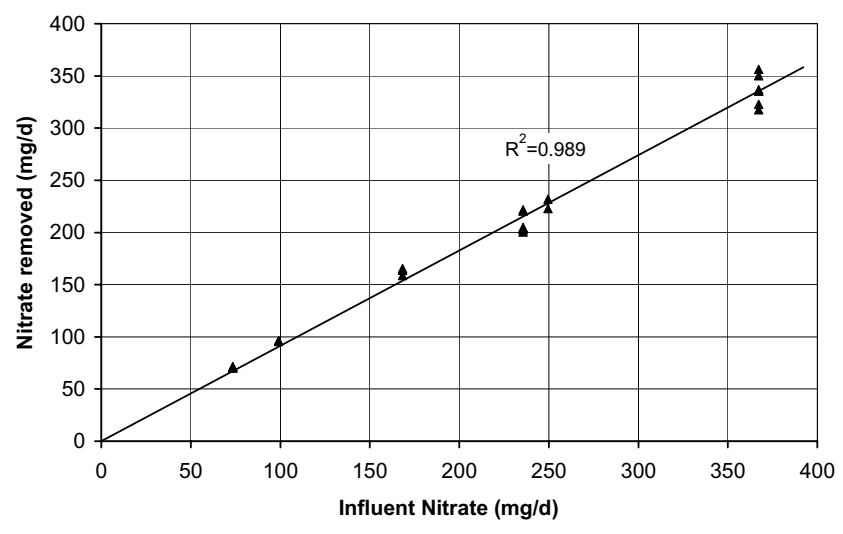

Figure 4

Effect of inlet $\mathrm{NO}_{3}{ }_{3}$ on $\mathrm{NO}_{3}{ }^{-}$removal in the $\mathrm{HDR}$

increased from $0.236 \mathrm{~m} / \mathrm{d}$ to $0.315 \mathrm{~m} / \mathrm{d}$; however, the removed nitrate was higher at higher velocity. This can be explained by the assumption that by increasing the flow velocity, resulting in an increase of inlet nitrate loading, the daily removal ratio of nitrate increased. The linear relationship between nitrate removal and temperature reported by Volokita et al. (1996b) from 19 to $30^{\circ} \mathrm{C}$ was not observed after $30^{\circ} \mathrm{C}$ in this study. Therefore $28^{\circ} \mathrm{C}$ (as a critical value close to $30^{\circ} \mathrm{C}$ ) was suggested as the optimum 


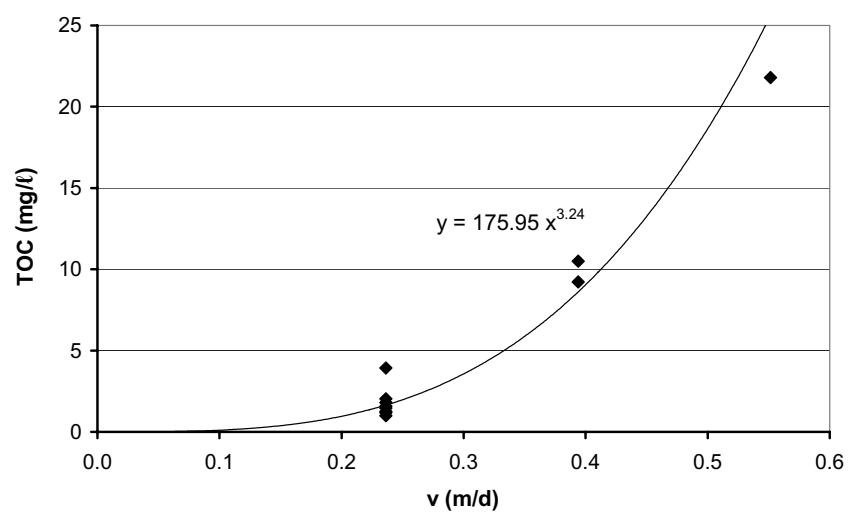

Figure 5

The effect of flow velocity on TOC outlet concentration in the HDR

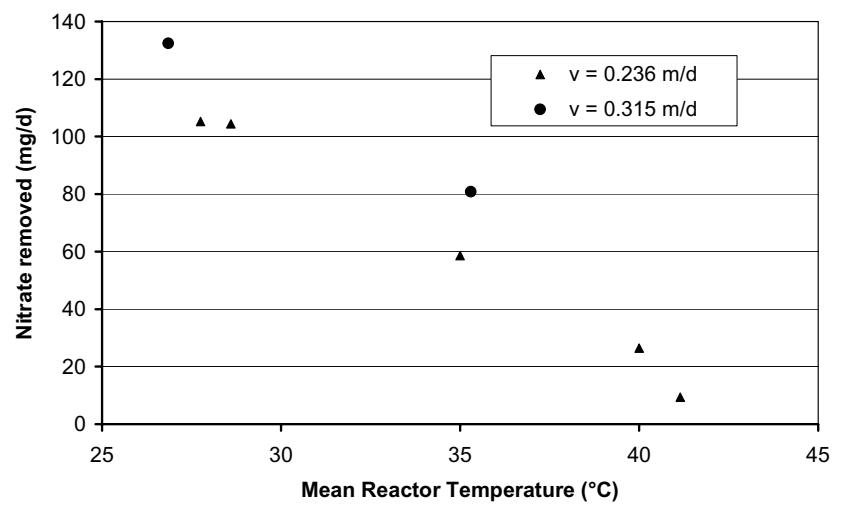

Figure 6

The effect of mean reactor temperature on nitrate removal in the HDR

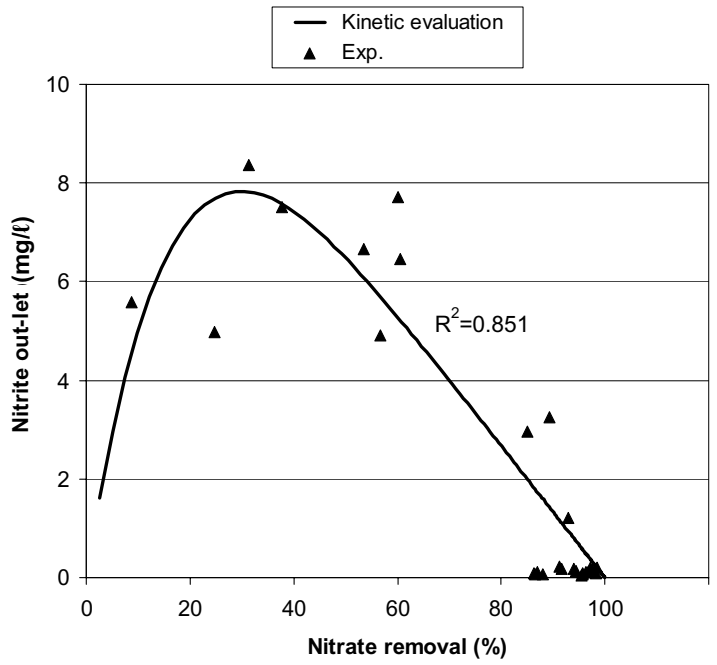

Figure 7

$\mathrm{NO}_{2}{ }^{-}$outlet concentration vs. $\mathrm{NO}_{3}$ removal efficiency in the $\mathrm{HDR}$

temperature to develop biological cotton-supported denitrification.

\section{Results from the HDR}

Main results of the biological process may be expressed in terms of TOC and bacterial colonies increase and the nitrite/ammonia accumulation in the outlet. Nitrite accumulation was observed only if denitrification was not completed as seen in Fig. 7. A non-linear curve fitting using a first-order kinetic for both nitrate to nitrite and nitrite to nitrogen gas transformations proved the highest correlation $\left(\mathrm{R}^{2}=0.840\right)$ between nitrite outlet concentration and nitrate removal efficiency (Fig. 7). The first-order kinetic constants were calculated as given below:

$$
\begin{array}{ll}
\mathrm{NO}_{3}^{-} \rightarrow \mathrm{NO}_{2}^{-} & K_{1}=2.6 \ell / \mathrm{d} \\
\mathrm{NO}_{2}^{-} \rightarrow \mathrm{N}_{2} \mathrm{O} \text { and } \mathrm{N}_{2} & K_{2}=15.9 \ell / \mathrm{d}
\end{array}
$$

Actually, the first-rate constant $\left(\mathrm{K}_{1}=2.6 \ell / \mathrm{d}\right)$ was given as a total nitrogen transformation constant by Canter (1997) for the greatest substrate availability. Using a $\mathrm{K}_{2}$ value of $15.9 \ell / \mathrm{d}$ the ratio between degradation velocity of nitrite and nitrate was obtained as 6.1 which was relatively higher than the experimentally obtained value of 4.3 by Chung and Bae (2002). They investigated both transformations separately in column reactors in a $\mathrm{pH}$ range of 7 to 9 and their values were found to be of the same order as those obtained in our study. However, the magnitude of the second-ratio constant $\left(\mathrm{K}_{2}\right)$ is still unclear. For instance, the reduction rate of nitrite was reported to be faster by Almeida et al. (1997) and Chung and Bae (2002) while Almeida et al. (1995) and Wild et al. (1995) expressed it to be slower than that of nitrate, depending on the experimental conditions. Keeping in mind that nitrite reductase is more sensitive to environmental conditions than nitrate reductase because the first one operates in periplasmic space while the last one operates on the cytoplasmic side of the cell membrane (Baumann et al., 1997; Chung and Bae, 2002), this kinetic evaluation may be assumed to be a preliminary study for the present data.

Meanwhile, the outlet ammonia concentration was measured in a range of 1 to $3.5 \mathrm{mg} / \ell$ following the column inoculation (data not shown). This detection contradicts the previous experiments reported in the literature (Volokita et al., 1996a; 1996b; Soares and Abeliovich, 1998; Soares et al., 2000) which did not detect any ammonia in the outlet. The reason for the ammonia presence in the outlet may be explained due to the iron content of inoculated cotton because iron can reduce nitrate to ammonia (Till et al., 1998; Zawaideh and Zhang, 1998). In fact, the peak of outlet ammonia concentration was recorded immediately after the column inoculation.

Outlet TOC concentration was usually lower than $15 \mathrm{mg} / \ell$ except for the period following the column inoculation. In the start-up period, TOC increased up to 100 to $140 \mathrm{mg} / \ell$ because cotton used was not of the purest quality and the inoculum still contained some soil.

Independently from the fluctuations which were observed in TOC (from 1.0 to $47.2 \mathrm{mg} / \ell$ ) and nitrate removal in biological process, the number of coliforms (CFU) in the denitrified water varied around $10 \mathrm{CFU} / \mathrm{m} \ell$, which was the same value of column outlet before inoculation. However, Volokita et al. (1996b) detected a high level of $10^{5} \mathrm{CFU} / \mathrm{m} \ell$ using R2A agar medium which is suitable to enumerate all heterotrophic bacteria (HPC). This underlines that neither coliforms nor HPC methods are suitable for monitoring denitrification process in terms of quantification of the pathogens which must not exist in the treated water.

\section{Trickling sand filter reactor (TSF)}

The trickling sand filter (TSF) was initially run as a post-treatment for the improvement of results of the biological process. The TSF was operated with a constant filtration rate of 

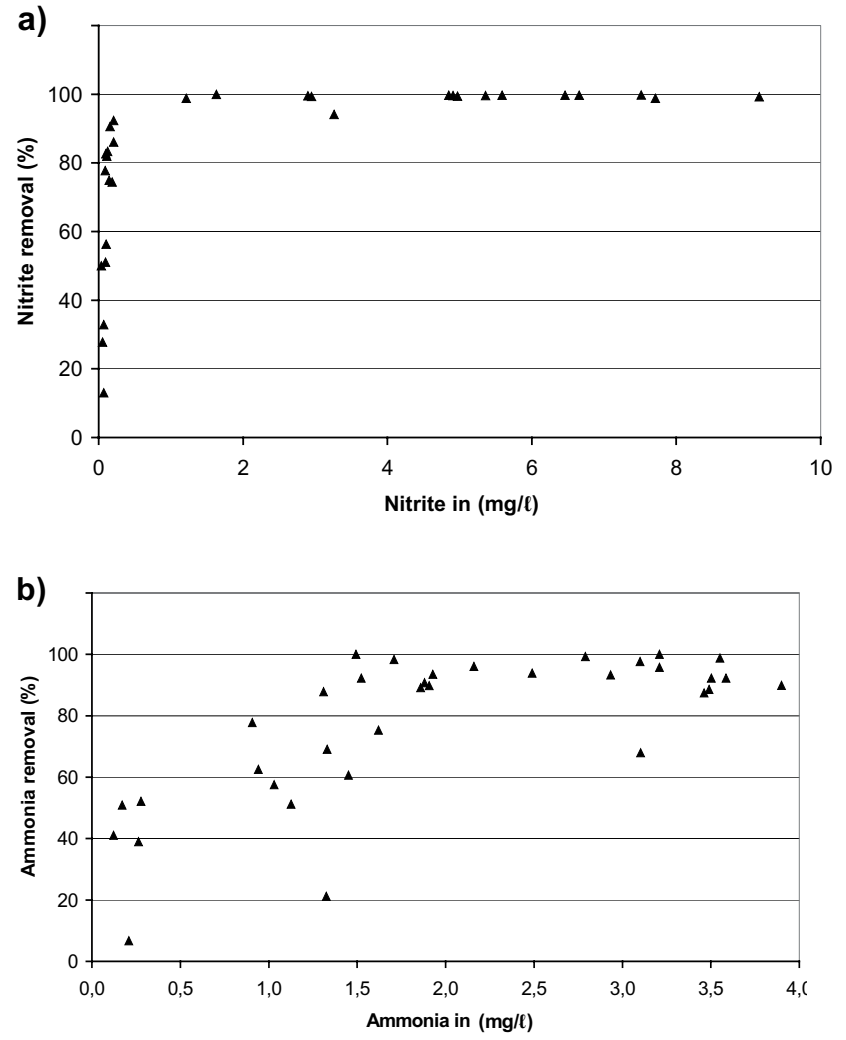

Figure 8

$\mathrm{N}-\mathrm{NO}_{2}{ }^{-}$and $\mathrm{N}-\mathrm{NH}_{3}$ removals in the $\mathrm{TSF}$

$36 \mathrm{~m} / \mathrm{d}$ independently from the influent flow rate (variable between 1.375 and $0.172 \mathrm{~m} / \mathrm{d}$ ) of the HDR. Ammonia and nitrite, and TOC parameters were monitored. Independently from flow rate of the HDR, nitrite and ammonia removals reached over 85 to $90 \%$ at 0.2 and $1.5 \mathrm{mg} / \ell$ of nitrite and ammonia concentrations, respectively as seen in Figs. 8a and 8b. Nitrate inlet concentration depended on the efficiency of the HDR and it varied from 0 to $85 \mathrm{mg} / \ell$. Nitrite outlet concentration was generally around 0.05 $\mathrm{mg} / \ell$ (with a peak of outlet of $0.4 \mathrm{mg} / \ell$ related to a high inlet concentration of $9 \mathrm{mg} / \ell$ ) while ammonia outlet concentration was generally around $0.3 \mathrm{mg} / \ell$ (with a peak of $1 \mathrm{mg} / \ell$ ).

It was evident that the removal of nitrite and ammonia occurred by biological nitrification into the filter as mentioned by Nakhla et al. (2003) with particular relevance to aerated filter media (Baykal et al., 1997). Aeration also assured a good reoxygenation of treated water; the oxygen saturation reached around $75 \%$ in the outlet of TSF (S3).

The nitrogen balance throughout the filter, considering inlet and outlet daily differences of ammonia and nitrite $v s$. total daily removed nitrogen, showed high correlation $\left(\mathrm{R}^{2}>0.884\right)$ as seen in Fig. 9a. However, this correlation increased more $\left(\mathrm{R}^{2}>0.980\right)$ when the concentrations of nitrogen higher than $4.5 \mathrm{mg} / \ell$ were excluded (Fig. 9b). This point should be evaluated further by defining the design parameters for the HDR. However, the data obtained in this study strongly suggest simultaneous nitrification and aerobic denitrification occurring in the filter in accord with Robertson et al. (1995) and Lorenzen et al. (1998).

The TOC outlet concentration (Fig. 10) was generally lower than $4 \mathrm{mg} / \ell$; nevertheless this value would not ensure adequate protection from the formation of disinfection by-products (DBPs) after disinfection with chlorine (Rook, 1974).

During the test period no backwashing was applied to the filter. But at the end of the test the column was empted to measure
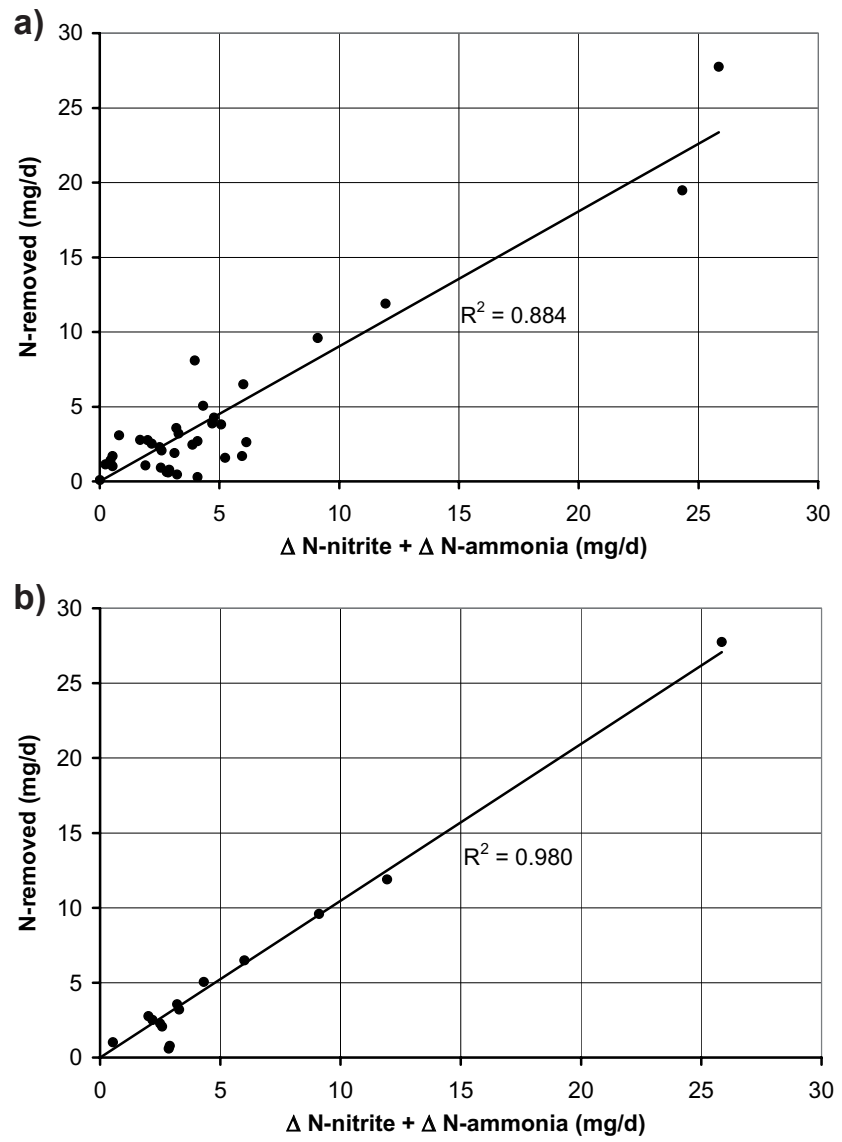

Figure 9

$\mathrm{N}-\mathrm{NO}_{2}{ }^{-}$(a) and $\mathrm{N}-\mathrm{NH}_{3}$ (b) inlet vs. $\mathrm{N}_{2}$ released into the TSF

TOC and nitrogen contents occurred due to biofilm formation through the column. The sand was chlorinated to stop the bioreaction and was left mixing slowly (60 r/min) for $24 \mathrm{~h}$ at ambient temperature. Both TOC and nitrogen contents were higher at the top layer, and decreased gradually with the column depth (Fig. 11). The efficacy of TSF for TOC removal is well known and the phenomena were related to biological processes occurring at filter-air interface (Wotton, 2002). However, in contrast to normal sand filtration, our conclusion on TOC distribution through the column depth, was that due to the aeration condition, the biofilm that formed was able to perform simultaneous nitrification and aerobic denitrification.

\section{Conclusions}

This study aimed to use cotton (solid carbon source) as energy source for HD for the removal of nitrate from nitrate-spiked drinking water. The HDR was followed by TSF to reoxygenate the denitrified water destinated for human consumption. The effective parameters such as flow velocity, temperature on whole system performance were investigated.

The HDR showed good nitrate removal capacity, with a daily removal of around $24.5 \mathrm{gN} / \mathrm{m}^{3}$. No significant nitrite accumulation occurred in the denitrified water. The ratio between consumed cotton and nitrate removal is comparable with the previous studies. The transformation of nitrate to nitrogen gas was characterised by first-order kinetics. The results obtained in this study contribute to define design parameters for the HDR. The process is greatly affected by temperature decreasing the performance vs. time. Optimal operational temperature was obtained around $28^{\circ} \mathrm{C}$. 


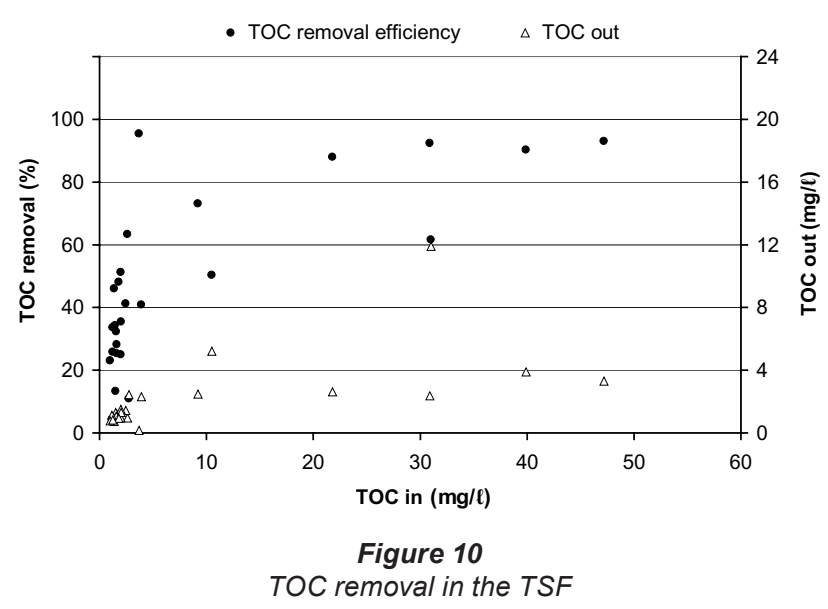

The TSF following the HDR contributed to the removal of TOC, nitrite and ammonia parameters. Hence, the TSF can be used in drinking water treatment as the post-simultaneous nitrification and aerobic denitrification process.

Before use of this systyem as PRB in situ the reactor configuration should be evaluated to allow the nitrogen bubbles to leave the system to avoid clogging which decreases longevity and permeability of the PRB. For example, the mixing of cotton with sand could overcome this problem. However, due to an increase in TOC in the treated water an integrative post-treatment should be considered.

\section{Acknowledgments}

The authors would like to thank Prof RMA Napoli for his suggestions, Dr Rosario Casale, Dr Giancarlo De Matteo and technician Paolo Napodano for their technical assistance and Dr Annachiara Forte for her moral support.

\section{References}

ALMEIDA JS, JULIO SM, REIS MAM and CARRONDO MJT (1995) Competition between nitrate and nitrite reduction in denitrification by Pseudomonas fluorescens. Biotechnol. Bioeng. 46 194-201.

ALMEIDA JS, REIS MAM and CARRONDO MJT (1997) Nitrite inhibition of denitrification by Pseudomonas fuorescens. J. Theor. Biol. 186 241-249.

ASLAN S and TURKMAN A (2004) Simultaneous biological removal of endosulfan $(\alpha+\beta)$ and nitrates from drinking waters using wheat straw as substrate. Environ. Int. 30 449-455.

BAYKAL BB and GUVEN DA (1997) Performance of clinoptilolite alone and in combination with sand filters for the removal of ammonia peaks from domestic wastewater. Water Sci. Technol. 35 (7) 47-54.

BAUMANN B, VAN DER MEER JR, SNOZZI M and ZEHNDER AJB (1997) Inhibition of denitrification activity but not of mRNA induction in Paracoccus denitrificans by nitrite at a suboptimal $\mathrm{pH}$. Antonie van Leeuwenhoek 72 183-189.

BOLEY A, MÜLLER WR and HAIDER G (2000) Biodegradable polymers as solid substrate and biofilm carrier for denitrification in recirculated aquaculture systems. Aquacult. Eng. 22 75-85.

CANTER LW (1997) Nitrates in Groundwater. Boca Raton: CRC Press.

CHUNG J and BAE W (2002) Nitrite reduction by a mixed culture under conditions relevant to shortcut biological nitrogen removal. Biodegrad. 13 163-170.

DELLA ROCCA C (2005) Biological Denitrification Of Drinking Water: Cotton And ZVI Supported Heteretrophic-Autrophic Deni-

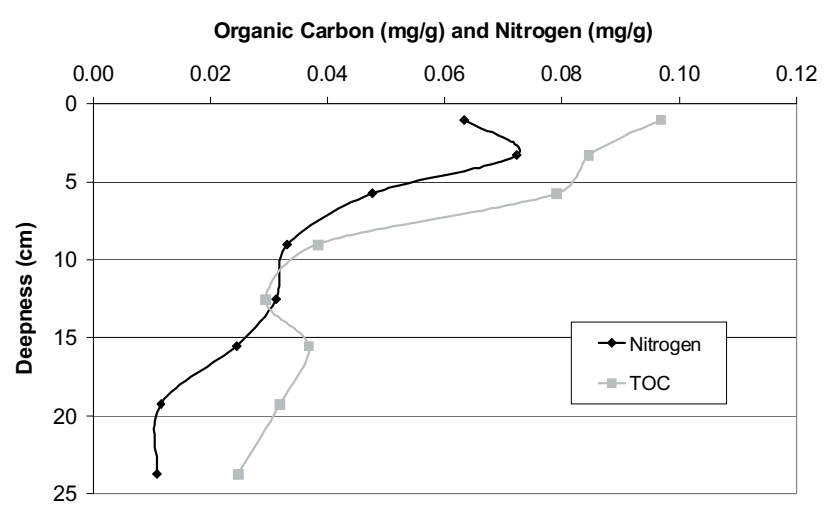

Figure 11

Distribution of TOC and N concentrations through the depth of the TSF

trification Of Nitrate Rich Potable Water. Ph.D. Thesis, University of Salerno, Engineering Faculty.

EEC (1998) Council Directive 98/83/EC of 3 November 1998 on the quality of water intended for human consumption. Off. J. Eur. Communities L330 32-54.

EEC (2002) Implementation of Council Directive 91/676/ECC concerning the protection of waters against pollution caused by nitrates from agricultural sources - Synthesis from year 2000 member States Report. COM/2002/404 final.

GAMBLE TN, BETLACH MR and TIEDJE JM (1977) Numericall dominant denitrifying bacterial from world soils. Appl. Environ. Microbiol. 33 (4) 926-939.

HER J and HUANG J (1995) Influence of carbon source and C/N ratio on nitrate/nitrite denitrification and carbon breakthrough. Bioresour. Technol. 54 45-51.

HUNTER WJ (2001) Use of vegetable oil in a pilot-scale denitrifying barrier. J. Cont. Hydrol. 53 119-131.

HUNTER WJ (2003) Accumulation of nitrite in denitrifying barriers when phosphate is limiting. J. Cont. Hydrol. 66 79-91.

LORENZEN J, LARSEN LH, KJÆR T and REVSBECH N (1998) Biosensor determination of the microscale distribution of nitrate, nitrate assimilation, nitrification, and denitrification in a diatom-inhabited freshwater sediment. Appl. Env. Microbiol. 64 (9) 3264-3269.

NAKHLA G and FAROOQ S (2003) Simultaneous nitrification-denitrification in slow sand filters. J. Haz. Mat. B96 291-303.

ROBERTSON LA, DALSGAARD T, REVSBECH N and KUENEN JG (1995) Confirmation of 'aerobic denitrification' in batch cultures, using gas chromatography and ${ }^{15} \mathrm{~N}$ mass spectrometry. FEMS Microbiol. Ecol. 18 113-120.

ROOK JJ (1974) Formation of haloforms during the chlorination of natural water. Water Treat. Exam. 23 234-243.

SCHIPPER LA and VOJVODIĆ-VUKOVIĆ M (2000) Nitrate removal from groundwater and denitrification rates in a porous treatment wall amended with sawdust. Ecol. Eng. 12 269-278.

SCHIPPER LA, BARKLE GF, HADFIELD JC, VOJVODIĆ-VUKOVIĆ $M$ and BURGESS CP (2004) Hydraulic constraints on the performance of a groundwater denitrification wall for nitrate removal from shallow groundwater. J. Cont. Hydrol. 69 263-279.

SOARES MIM, BELKIN S and ABELIOVICH (1989) Clogging of microbial denitrification sand columns: carbon regime, gas accumulation and hydraulic properties. Water Res. 30 965-971.

SOARES MIM, BELKIN S and ABELIOVICH (1991) Denitrification in laboratory sand columns: gas bubbles or biomass accumulation? Z. Wasser-Abwasser-Forsch. 22 20-24.

SOARES MIM and ABELIOVICH A (1998) Wheat straw as substrate for water denitrification. Water Res. 32(12) 3790-3794.

SOARES MIM (2000) Biological denitrification of groundwater. Water Air Soil Pollut. 123 183-193.

SOARES MIM, BRENNER A, YEVZORI A, MESSALEM R, LEROUX Y and ABELIOVICH A (2000) Denitrification of ground- 
water: Pilot-plant testing of cotton-packed bioreactor and post-microfiltration. Water Sci. Technol. 42 (1-2) 353-359.

STANDARD METHODS (1998) Standard Methods for the Examination of Water and Wastewater (20 th edn.) American Public Health Association/American Water Works Association/Water Environment Federation, Washington DC, USA.

TANNENBAUM SR and GREEN LC (1985) Selected Abstract on the Role of Dietary Nitrate and Nitrite in Human Carcinogenesis. International Cancer Research Data Bank Program, National Cancer Institute, Washington, D.C

TILL BA, WEATHERS LJ and ALVAREZ PJJ (1998) Fe(0)-Supported autotrophic denitrification. Env. Sci. Technol. 32 634-639.

USEPA (1995) National Primary Drinking Water Regulations. USEPA 811-F-95-002-T.

USEPA (1998) Permeable reactive barrier technologies for contaminant remediation. USEPA 600-R-98-125.

VOLOKITA M, BELKIN S, ABELIOVICH A and SOARES MIM (1996a). Biological denitrification of drinking water using newspaper. Water Res. 30(4) 965-971.
VOLOKITA M, ABELIOVICH A and SOARES MIM (1996b) Denitrification of groundwater using cotton as energy source. Water Sci. Technol. 34 (1-2) 379-385.

WHO (2003) Guidelines for Drinking-Water Quality (3rd edn.). World Health Organization.

WILD DR, VON SCHULTHESS and GUJER W (1995) Structured modeling of denitrification intermediates. Water Sci. Technol. 31 (2) 45-54.

WINNEBERGER JH (1982) Nitrogen, Public Health, and the Environment. Ann Arbor Science Publishers, Inc., Ann Arbor, Michigan. p. 5.

WOTTON RS (2002) Water purification using sand. Hydrobiol. 469 193-201.

ZAWAIDEH LL and ZHANG TC (1998) The effects of $\mathrm{pH}$ and addition of an organic buffer (HEPES) on nitrate transformation in $\mathrm{Fe}^{0}$-water systems. Water Sci. Technol. 38 (7) 107-115. 